\title{
OBSERVATIONS ABOUT THE PINTADERAS FROM THE CUCUTENI CULTURE AREA IN ROMANIA
}

Dragomir Popovici

\section{OBSERVAȚII PRIVIND PINTADERELE DIN AREALUL CULTURII CUCUTENI DE PE TERITORIUL ROMÂNIEI}

\section{Rezumat}

Pană în prezent cercetătorii romani nu au dedicat nici un studiu pintaderelor descoperite în arealul culturii Cucuteni. Prezentul studio îşi propune analizarea unui număr de 41 de piese pentru care există date mai clare, deşi pentru nici una dintre piesele publicate nu se cunoaşte contextul detaliat al descoperirii. Studiul tipologic releva existența unor diferențieri din punctul de vedere al formei dar şi din cel al decorului. Utilizarea, în condițiile în care condițile de descoperire nu pot fi precizare cu certitudine rămane incertă. O serie de ipoteze sunt trecute in revista. Se subliniază însă valoarea acestui tip de piese pentru evidenţierea existenței şi funcţionării unor sisteme de comunicare intra sit sau inter situri şi vehicularea unor simboluri acceptate şi receptate ca atare.

Cuvinte cheie: Pintadere, eneolitic, Cucuteni, schimb.

Keywords: Pintaderas, Eneolithic, Cucuteni, exchange.

According to the available data, pintaderas are known within the Cucuteni A Phase (till the present time only in the A2 and A3 stages), being documented in 16 settlements by at least 48 pieces, most of them complete. We were able to find more or less precise or complete data for only 41 pieces. None of these contain the archaeological context of the discovery.

The Romanian Historiography has not known, till the present time, no study dedicated to these discoveries; there are only references and brief discussions.

\section{Distribution}

Pintaderas were discovered on a widespread area in South Eastern Europe and also till Austria and Germany, covering a time interval that includes all the neo-eneolithic (Makkay 1984; Neugebauer-Maresch 1999; Renfrew 2003).

\section{The Cucutenian area}

The analysis and interpretation of this type of pieces is, from our point of view and in most cases, severely affected by the lack of the conditions of the discovery. To be more precise, the contexts of the discoveries are missing and this diminishes not only our possibility to perform a complete analysis but also the potential interpretation of the results.

Most published discoveries - eight pieces - are from the Poduri site (Monah et al. 1982; Makkay 1984, considers that also the piece from $\mathrm{Pl} . \mathrm{V}-5$ is a pintader, but the absence of the decoration in this case prevents us from agreeing to this opinion, as the piece may sooner be a „cone”; Monah et al. 2003, p.197198 , nr. 219, 220, 221, 222, 223, 224, the latter having the active part diameters of $6,7 \mathrm{~cm}, 6,4$ $\mathrm{cm}, 6,8 \mathrm{~cm}, 6,2 \mathrm{~cm}, 5,8 \mathrm{~cm}, 4,7 \mathrm{~cm})$. The present decoration is the more or less folded spiral. All were discovered in Cucuteni A2 contexts.

Eight pieces with a decorated active part were also discovered at Frumuşica, together with another 13 pieces with no decoration (Matasă 1946, pl. II/366-372; Makkay 1984, considers - and we agree - that the latter, due to their very small dimensions and also lack of 
decoration on the active part, cannot be considerd as pintaderas; in the case of the pieces with a decorated active part their diameters were of $7,3 \mathrm{~cm}, 6,7 \mathrm{~cm}, 4,2 \mathrm{~cm}, 6 \mathrm{~cm}$, probably $4,2 \mathrm{~cm}, 4,4 \mathrm{~cm}$ and $6,3 \mathrm{~cm}$ ).

Such pieces were also discovered in other settlements: at least six at Bod, with the diameter of the active part between $4-7 \mathrm{~cm}$, (Teutsch, 1903b, p. 368, 392, Fig. 12; 13; 14a,b,c; 99-38,39, 40; Makkay 1984, p. 14-15).

It is mentioned the discovery by Fr. Laszlo, during his researches at Ariuşd, of a few (probably five or six) pieces in Level VII, so very probably Cucuteni A2, (László 1911, p. 237, fig. 78; Laszlo 1973; idem, 1974; Makkay 1984 , one of these pieces having the active part diameter of 5,6 cm).

It is still Fr. Laszlo, during his researches at Olteni, the discoverer of five pieces, two of them having diameters of $5 \mathrm{~cm}$ and $5,1 \mathrm{~cm}$, respectively (Laszlo 1911; Laszlo 1973; idem, 1974; Makkay 1984, p.42-43, Fig. XVIII-181; XX-180).

3 pieces were discovered at Hăbăşeşti (Dumitrescu 1954, p. 466, fig. 44/1, 5; the piece shown at Fig. 47/11 is not sure a pintadera, as it could also be a "cone", but the decoration from its active part could be considered as an argument in the favor of its integration in this category; the diameters of the active parts are of $3,3 \mathrm{~cm}, 4,5 \mathrm{~cm}, 9 \mathrm{~cm})$.

Two pieces were discovered at Ruginoasa, (Dumitrescu 1932, p. 66, fig. 10/1, 8) and another two at Scânteia, (Mantu, Țurcanu 1999, nr. 352, 353 with diametres of 5 $\mathrm{cm}$ and $4,2 \mathrm{~cm}$ ), the latter being fragmentary.

In the Tîrpeşti settlement only one piece was discovered (Marinescu-Bîlcu 1981, fig. $200 / 8$, with the active part diameter of 5,1 cm).

Only one piece was also discovered at Păuleni, (Lazarovici et al. 2000, Pl. X/4). If in what regards the site from Râpa lui Bodai we can consider this situation as final, at Păuleni the situation can be considered only temporary, as digging campaigns shall continue.

Other discoveries are mentioned at Reci as provenient from Fr. Laszlo's diggings, (Laszlo 1973; idem, 1974; Makkay 1984), Bursuci-Cărămidărie - Vaslui County, (Coman 1980, p.131, Fig. 106-1 where the piece is attributed to the Starcevo-Criş Culture; Makkay
1984, p. $67-68$, Fig. XXXI-292 states that it is more probably that this piece belongs to the Cucuteni A inhabitance level, as proved by the pottery discovered here), Igeşti-Scândureni Vaslui County, (Coman 1980, p. 77, Fig. 106-2; Makkay 1984, p. 68, Fig. XXXI-293), CostişaNeamț County - with two pieces (Vulpe, Zamoşteanu 1962; Makkay 1984, p. 16, Fig. XXVII-38, 39, states that the piece belongs to the Cucutenian Phase A inhabitance, certified here).

Published results also show the presence of a piece in each of the Calu-Piatra Şoimului and Mărgineni-Cetățuia settlements, both from the Cucuteni A2 stage (Mantu, Dumitroaia 1997, p.186, nr. 34, 33, with diameters of the active parts of 5,9 and $5,1 \mathrm{~cm}$ respectively; Preoteasa, 2002, p.28, nr.27). Such a piece is provenient also from the Cucuteni-Cetățuie (probably), Phase A, (Passek 1949b, Fig. 11).

During the researches performed at Topile a piece was discovered that resembles with the pintaderas from the typological point of view (Marinescu-Bîlcu 1977a, p.132, Fig. 4/2), with a well-individualized handle and a circular active part. The lack of the decoration proves at least a different use; if we take into account the pieces from Poduri, Izvoare, etc. this situation is not singular.

7 pieces attributed to the Cucuteni $\mathrm{A}$ are mentioned as discovered at Izvoare (Vulpe 1957, p.237, Fig.239-1; 240-1-5; p.254, Fig. 257-5). Their dimensions (diameters of their inferior parts vary between 1,6 and 2,8 cm), added to the lack of the decoration, make us believe that their use as pintaderas seems very improbable, as it's more probable that these are more similar to the frequent cones discovered in the Cucutenian Phase A settlements. We remark that it is stated that the latter of these was crafted in marl and not clay, as it is the general situation (Makkay 1984, p.28, erroneously states that this was made of marble).

In the Tripolitan area the discovery from the Luka Vrublevețkaia site is worth mentioning: five clay cones out of which one, with a diameter of $2,7 \mathrm{~cm}$, was considered as a potential pintadera (Bibikov 1953, p. 201, Pl. 71; Makkay 1984), but this seems improbable if we take into account not only the dimensions but also the lack of any decoration. 


\section{Paste}

The pintaderas are modeled in high quality clay, burnt to brown - yellow, more seldom at red, not very carefully finished.

Tipology

In what regards the formal characteristics, we observe that this type of pieces has two parts whose external aspects differ, very probably due to their utilization: the upper part that in principle can be used to manipulate the piece and the lower part - the active one - decorated, that is used after the decoration to print the model when covered by a color.

1. The first type is characterized by a general cone shape (6 items, discovered at Ariuşd -2 items at Bod and then only one at Frumuşica, Hăbăşeşti and Igeşti).

This type is very much assembling the so called ,cones" discovered relatively frequent in various Cucutenian settlements. Even though the shape and sometimes even the dimensions allow the connections and similarities between these pieces, we tried to dissociate them as we believe that there is a major difference lying in the presence of the model on the lower part.

1.1. A variety with a circular active part of the piece is illustrated by five of the items we have data on, discovered at Frumuşica, Ariuşd, (two), Bod, Hăbăşeşti and Igeşti.

1.2. The second variety has the shape of a rectangle with rounded corners. But if we take into account the shape of the active part, then the shape of the handle is superimposed and thus the general shape is more triangular than conical, with a rounded apex.

This variety consists of only one item, discovered at Bod. Another piece whose active part has the same characteristics but with no clear data about the handle is also provenient from the same site.

1.3. The third is characterized by the oval shape of the active part. The three items attributed to this variety were discovered at Ariuşd, Calu and Bursuci. Nevertheless, the discrimination of this variety cannot be certain from our point of view, as the published materials do not clearly present the shape of the handle. Under these circumstances, we believe that the discoveries can be more probably associated to this variety, anyway resembling variety 1.2 .

2. The second type has an obviously modeled handle that helps the use of the piece, with variable heights $(3-4 \mathrm{~cm})$. Using this criterion we were able to make the difference between two varieties.

The active part is modeled as a disk or a plaquette, with variable thickness but always below $1 \mathrm{~cm}$, with an average diameter of about $5 \mathrm{~cm}$, (in the case of round ones). The attached handle is cylinder or slightly conical.

2.1. A first variety is determined by the shape of the upper part, handle respectively, that in this case has a rhomboidal flat shape with a hole at its upper part. The active part has a rectangular (square) shape. Only one item of this kind has been discovered till now, at Frumuşica.

2.2. The second variety shows a cylindrical or slightly conical handle, with the upper part rounded and circular active part.

This is the most frequent among all the varieties discovered until now in the Cucutenian area, including 30 items (31, if we include also the item from Topile) found in all settlements where pintaderas have been discovered, excepting for Ariuşd, Bursuci and Păuleni.

Such pieces were found at Poduri -7 items and Frumuşica - 3. Two pieces were discovered in each of the following sites: Bod, Hăbăşeşti, Ruginoasa and Scânteia, while a single item was discovered at Costişa, Ariuşd, Olteni, Bursuci, Târpeşti, Mărgineni and Calu.

Some items, such as those discovered at Poduri (6 pieces), Frumuşica (3 pieces), Bod and Mărgineni (one piece each), show circular transverse perforations of the "handle" (its perforation was not found in all discovered pieces but it nevertheless has a significant frequency; see also Makkay 1984; LichardusItten et al. 2002).

\section{The decoration}

We use this term even though it is hard to state that the elements appearing on the active part may actually be these pieces' proper decoration.

In what regards its structure, the decor can be divided into three categories: 
1. The first is characterized by the presence of the spiral with two varieties.

1.1. This variety has the simple spiral as décor; it is made on an oval shaped active part. Till the current time only two pieces have been discovered at Ariuşd and Calu.

1.2. The characteristics of the second variety are the contiguous "clinging" spirals, such as observed at one piece discovered at Bod, with a rectangular shaped active part.

2. This category is generally characterized by decoration elements resulted from the sectioning of the spiral décor. Four varieties were observed, whose definition was based only on the décor characteristics and less on the crafting techniques.

2.1. This variety has as a main decoration element the sectioned spiral coil, as observed at 21 pieces from the dwellings at Poduri, (3 items), Frumuşica, (4 items), Bod, (4 items), Ariuşd, (1 items), Hăbăşeşti, (2 items), Olteni, (2 items), Ruginoasa, (2 items), Scânteia, (1 item), Târpeşti and Mărgineni, 1 exemplar each.

2.2. The "hanged" coils are a less frequent décor, being documented only for 7 pieces discovered in 4 settlements: Poduri- 4 items, Frumuşica-1 items, Igești-1 item and Păuleni-1 item.

2.3. The décor consisting of concentric circles was observed in only one case, a piece discovered at Scânteia.

2.4. Only one piece, discovered at Frumuşica, has a sectioned coil of an angle spiral.

3. This category groups deepened, incised or not décor, that is generally constituted of elements of sectioned spiral décor: parentheses, rows of parentheses, angular incisions disposed either in rows. At least for the time being we consider that these structure also varieties of this type of décor.

3.1. Only one item discovered so far at Bod has a décor consisting of two opposed half circles.

3.2. Another item, discovered at Costişa, has a décor constituted of two parallel rows of curve incisions.

3.3 This variety is characterized by a décor consisting of a zig-zag incised line, as it can be observed on a piece discovered at Costişa.
3.4. The fourth variety has a more elaborate décor that implies the separation of the decorative area in four equal parts, each of them covered by incised lines disposed at angles of $90^{\circ}$. This was observed on pieces discovered at Frumuşica, Bursuci and Cucuteni.

\section{General characteristics}

The synthesis of the previously mentioned elements offers several observations that may be considered as expressive for this group of pieces.

Thus, in what regards the shapes, we observe the high frequency of variety 2.2 (26 pieces), and in what regards the décor, the most frequent is variety 2.1 , followed by 2.2 (generally associated and counting together 28 items). This homogeneity characterizes the pintaderas from the Cucutenian area. The crafting techniques are, nevertheless, much more various.

Most of the pieces were discovered in settlements with a complex stratigraphy, which seems to be very suggestive. This could be an argument showing the very probably very special role that these items played in the Cucuteni A Phase.

In the same way, at the settlement level we can remark the higher homogeneity of these groups of pieces at Frumuşica, Bod, Hăbăşeşti, Olteni, Ruginoasa, Târpeşti and Mărgineni.

The group of pieces from Poduri is structured in two parts that differ only from the point of view of the decor.

The characteristics belonging to the group from Frumuşica resemble those from Poduri, with the observation that here the décor is more diversified, predominant being type 2.1, but also with decors of type 2.4 and 3.4.

The lack of supplementary data regarding their contexts impedes us for the time being to draw any other conclusions.

Out of the known pieces, only 13 have a circular hole of the upper part. Most of them, 7, were found at Poduri, 3 at Frumuşica and one each at Bod, Scânteia and Mărgineni. It is possible that this detail suggests a certain type of use or in any case a higher mobility (?) of the pieces. 
Even though for the moment the the situation is not very eloquent, it may be still considered as interesting the mentioning of pieces having traces of paint, mainly red, discovered at Frumuşica (3 pieces) and Olteni (1 piece).

It is obvious that, due to the lack of more numerous discoveries, we cannot certainly affirm for the time being the existence of any regional differentiations, even though may have probably existed.

We also remark that such pieces were not discovered at Dumești, Drăgușeni or Preutești; if this situation is not denied by future discoveries must be explained.

\section{Functionality and use}

We observe that their appearance and use coincides to the period of Cucuteni A Phase, at least according to the existing data. Till the current time no pieces are known as belonging to Phases Cucuteni A-B and B.

It is also interesting that no such pieces were discovered in pre-Cucutenian settlements nor in the areas of the Petreşti and Boian cultures.

This situation is recorded for Tripolian settlements, East of Prut River.

Nevertheless, these are known in Gumelniţean settlements, being at about three times more frequent in the Southern part than on the Northern part of the Danube River.

Recent studies (Chapman 2000; idem 2001; Sîrbu, Pandrea 2003; Renfrew 2003), showed some aspects regarding the use and significance of the existence not only for the pintaderas but also for various signs incised on the bottoms of some pottery. The latter are quasi inexistent in the Gumelnitean settlements and totally missing in the Cucutenian ones, being nevertheless known in the Boian, Vinca and Turda cultures areas.

This situation rise several problems regarding their origin and use and especially their significance.

The sometimes careless finishing of the piece and even of the décor may allow us conclude the hypothesis of a more profane use of this type of pieces.
No matter which was the use, we must remark the unity of the décor, the circle or the spiral coil, used in the entire area between South-eastern Transylvania to Prut River. This apparent (?) unity suggests a resembling, if not identical, initial background (the spiral coil) and purpose. This situation may affirm that some symbols were understood and accepted on pretty wide areas. This observation must also be correlated with the décor, either painted or incised, whose fundamental decorative element is the spiral. This décor is, as mentioned, also present on very wide spaces. We believe that we must underline the fact that, even though this type of pieces was not used to decorate the pottery, it nevertheless takes elements or parts of the décor present on pottery. This obvious unity proves semantic values of the décor that must be discussed further on.

It seems interesting to mention that, in what regards this type of pieces, the Cucuteni A Phase area is individualized in comparison with, for example, the Early Thessalian Neolithic where the variety of the decors is higher. There a possible existence of exchange systems and circuits, specific between various communities, was also suggested (Halstead 1989, p. 68 and following).

Almost all the opinions expressed about the use of this type of pieces (see also Makkay 1984; Bailey 2000; Chapman 2001; Renfrew 2003) prove a certain conviction that may be connected with the printing of some decoration elements (?), symbols, (?), marks, (?), on perishable materials (at least, on materials that were less resistant than the ceramics), with the help of motifs and colors (traces of colors, mainly red, being observed in several cases, respectively at Frumuşica and Olteni).

This situation raises the problem of circulation and sending of symbols and notions that are accepted and recognized, at least in some areas or within some communities. From this point of view, the characteristics of the pieces from Poduri prove themselves at least interesting. 


\section{BIBLIOGRAPHY}

Bailey, Douglass 2000 - D. Bailey, W. Douglass, BalkanPrehistory. Exclusion, Incorporation and Identity, Routledge, London-New York, 2000.

Bibikov 1953 - S.N. Bibikov, Rannetripolskoe poselenie Luka-Vrublevețkaia na Dnestre, in MIA, 38, 1953. Chapman 2000 - J. Chapman, Fragmentation in archaeology. People, places and broken objects in the prehistory of south-eastern Europe, London and New York, 2000.

Chapman 2001 - J. Chapman, Intentional fragmentation in the Neolithic and Copper age of South East Europe: incised signs and pintaderas, în Fl. Draşovean, (red.), Festschrift fur Gheorghe Lazarovici, Timişoara, 2001.

Coman 1980 - G. Coman, Statornicie, continuitate. Repertoriul arheologic al județul Vaslui, Bucureşti, 1980.

Dumitrescu 1933 - H. Dumitrescu, La Station préhistorique de Ruginoasa, în Dacia, (S.V.), III-IV, 1933, 1927-1932.

Dumitrescu 1954 - H. Dumitrescu, Unelte de producție, Plastica, Diferite obiecte, în Vl. Dumitrescu, H. Dumitrescu, M. Petrescu-Dîmbovița, N. Gostar, Hăbăşeşti. Monografie arheologică, 1954.

Halstead 1989 - P. Halstead, The economy has a normal surplus: economic stability and social change among early farming communities of Thessaly, Greece, în P. Halstead, J. O Shea (ed.), Bad Year Economics : Cultural Responses to Risk and Uncertainty, Cambridge, C.U.P., 1989.

László 1911 - F. László, Háromszék vármegyei praemykeniaei jellegii telepek, (Stations de l' epoque pré micenniene dans le comitat de Haromszek), Dolgozatok, Cluj, 1911, 2, 2.

Lazarovici et al. 2000 - Gh. Lazarovici, A.S. Luca, D. Buzea, C. Suciu, Descoperirile eneolitice de la Păuleni, în Angustia, 5, 2000.

Lichardus-Itten et al. 2002 - M. Lichardus-Itten, J.-P. Demoule, L. Perničeva, M. Grebska-Kulova, I. Kulov, The Site of Kovačevo and the Beginnings of the Neolithic Period in Southwestern Bulgaria. The French-Bulgarian excavations 1986-2000, în Marion Lichardus-Itten, Jan Lichardus und Vassil Nikolov, Beiträge zu Jungsteinzeitlichen forschungen in Bulgarien, Bonn, 2002.

Mantu, Dumitroaia 1997 - C.-M. Mantu, Gh. Dumitroaia, Catalogue, în C.-M. Mantu, Gh. Dumitroaia, A. Tsaravopoulos, (eds.), Cucuteni. The last chalcolithic Civilisation of Europe, Thessaloniki, 1997.

Mantu, Țurcanu 1999 - C.-M. Mantu, S. Ţurcanu, Scânteia. Cercetare arheologică şi restaurare, Iaşi, 1999.

Makkay 1984 - J. Makkay, Early Stamps Seals in South-East Europe, Budapesta, 1984.

Monah et al. 1982 - D. Monah, Şt. Cucoş, D. Popovici, S. Antonescu, Săpăturile arheologice din tell-ul cucutenian Dealul Ghindaru, com. Poduri, jud. Bacău, în C. A., V, 1982.

Monah et al. 2003 - D. Monah, Gh. Dumitroaia, F. Monah, C. Preoteasa, R. Munteanu, D. Nicola, Poduri-Dealul Ghindaru. O Troie în Subcarpaţii Moldovei, Piatra Neamţ, 2003.

Matasă 1946 - C. Matasă, Frumuşica. Village préhistorique à céramique peinte dans la Moldavie du Nord, Roumanie, Bucureşti 1946.

Marinescu-Bîlcu 1981 - S. Marinescu-Bîlcu, Tîrpeşti. From Prehistory to History in Eastern Romania, B.A.R., I.S., 107, Oxford, 1981.

Neugebauer-Maresch 1999 - Ch. Neugebauer-Maresch, Mittelneolithikum: Die Bemaltkeramic, în Eva Lenneis, Christine Neugebauer-Maresch, Elisabeth Ruttkay, Jungsteinzeit im Osten Österreichs, NPWien, 1999.

Passek 1949 - T.S. Passek, Periodizacija tripol'skih poselenij, în M.I.A., 10, 1949.

Preoteasa, C., 2002 - C. Preoteasa, Catalogul exponatelor, în Gh. Dumitroaia, D. Monah (coord.), Artă eneolitică. Cucuteni, P. Neamț, 2002.

Renfrew 2003 - C. Renfrew, Special Clay Objects: Cylinders, Stamp Seala, Counters, Biconoids, and Spheres, în E.S. Elster, C. Renfrew, (eds.), Prehistoric Sitagroi: Excavations in Northeast Greece, 1968 1970, Vol. 2: The Final Report, Monumenta Archaeologica 20, Los Angeles, 2003.

Sîrbu, Pandrea 2003 - V. Sîrbu, S. Pandrea, Vasele cu semne pe fund din neoliticul dezvoltat în spaţiul carpato-balcanic, în Banatica, 16, I, 2003.

Teusch 1903 - J. Teusch, Ausgrabung der Priesterhügel (Montenegro) în M.d. prähist. Komm. Der K.K. Akad. D. Wissenschaften, Wien, 1903. 
Vulpe, Zamoşteanu 1962 - Al. Vulpe, M. Zamoşteanu, Săpăturile de le Costişa, M.C.A., VIII, 1962. Vulpe 1957 - R. Vulpe, Izvoare. Săpăturile din 1936-1948, Bucureşti, 1957.

\section{LISTA ILUSTRATIEI}

Fig. 1. Harta siturilor în care au fost menționate pintadere

Fig. 2. Tipologia pindarelor - forma 1

Fig. 3. Tipologia pindarelor - forma 2

Fig. 4. Repartiția pintaderelor decorate.

Fig. 5. Repartitia pintaderelor decorate.

Fig. 6. Repartiția pintaderelor decorate.

Fig. 7. Repartiția pintaderelor decorate.

\section{Dragomir Popovici}

Romanian National History Museum

12, Calea Victoriei, 030026 Bucharest, Romania

dnp@mnir.ro 